\title{
The Analysis of English Word Formations Used on Brand Names Found in Indonesian Products
}

\author{
Giyatmi, Endang Dwi Hastuti, Ratih Wijayava, Sihindun Arumi \\ Universitas Veteran Bangun Nusantara Sukoharjo \\ Jl.Letjend Sujono Humardani No.1 Jombor Sukoharjo, 57512 \\ giyatmi85jimmy@gmail.com
}

\begin{abstract}
This research aims at describing how brand names with English in Indonesian products are created. To analyze the data found the researchers applied English word formation in English morphology. This is a descriptive research. The data were brand names using English found in Indonesian product which were taken from three supermarkets in Solo namely Hypermart Solo Grand Mall, Hypermart Gorro Assalam, and Carefur from February up to April 2010. The research found that the brand names with English in Indonesian products can be created by applying word formation such as compounding, blending, affixation, reduplication, onomatopoeia, abbreviation, acronym and clipping. The process of compounding consists of pure compounding and modification compounding, The process of blending includes the first syllable of the first words and the first syllable of the second words, the first syllable of the first words and the second syllable from the front of the second words., the first words and the last syllables of the second words, the first words and two syllables from the front of the second words, two syllables from the front of the first words and the second words, two syllables from the front of the first words and the first syllable of the second words, the first words and the two last syllables from the back of the second words, and the first words and the first syllables of the second
\end{abstract}


The Analysis of English Word Formations Used on Brand Names Found in Indonesian Products

words. The affixation process covers prefixes pro-, -bio and suffixes $-\mathrm{y}$, er, -ness, -ish, and -s. The process of reduplication includes pure modification, modification with intensifier meaning and reduplication with sound change. The process of abbreviation found is pure abbreviation and acronym. The process of clipping includes the clipping of letter and syllables.

Keywords: brand names, English word formation.

\section{Abstrak}

Penelitian ini bertujuan untuk menjelaskan bagaimana nama dagang dengan bahasa Inggris di produk Indonesia diciptakan. Untuk menganalisis data yang ditemukan, para peneliti menerapkan teori pembentukan kata bahasa Inggris dalam morfologi bahasa Inggris. Penelitian ini merupakan penelitian deskriptif. Data penelitian ini adalah nama dagang berbahasa Inggris yang ditemukan dalam produk Indonesia yang diambil dari tiga supermarket di Solo yaitu Hypermart Solo Grand Mall, Hypermart Gorro Assalam, dan Carefur dari Februari hingga April 2010. Penelitian ini menemukan bahwa nama dagang berbahasa Inggris dalam produk Indonesia dapat diciptakan dengan menerapkan pembentukan kata seperti pemajemukan, pencampuran, penambahan imbuhan, reduplikasi atau pengulangan, onomatopoeia, singkatan, akronim dan pemotongan. Proses pemajemukan terdiri dari pemajemukan murni dan pemajemukan dengan modifikasi, Proses pencampuran terjadi melalui pencampuran suku pertama kata pertama dan suku pertama kata kedua, suku pertama kata pertama dan suku kedua dari depan kata kedua, kata pertama dan suku terakhir kata kedua, kata pertama dan dua suku pertama dari depan kata kedua, dua suku pertama dari depan kata pertama dan kata kedua, dua suku pertama dari depan kata pertama dan suku pertama kata kedua, kata pertama dan dua suku terakhir dari belakang kata kedua. kata pertama dan suku pertama kata kedua. Proses afiksasi meliputi awalan pro, -bio dan akhiran -y, eh, -ness, ish, dan -s. Proses reduplikasi meliputi modifikasi murni, modifikasi untuk penyangatan makna dan reduplikasi dengan perubahan suara. 
Proses singkatan ditemukan adalah singkatan murni dan akronim. Proses pemotongan terdiri dari pemotongan huruf serta pemotongan suku kata.

Kata Kunci: Nama dagang, proses pembentukan kata berbahasa Inggris.

\section{Introduction}

What's in a name, a very popular quotation taken from Romeo and Juliet by Shakespeare, means that name is not that important. However, it sometimes means so much, for instance a product name or sometimes is called brand name. A brand name is the identity of specific product, service or business. A legally protected brand name is called a trademark.

The society will know a certain product from its name. After all, hopefully, the society will buy and use the product offered. It is necessary to develop brand name that can be used widely. It sometimes takes more time to decide the name of a new product than on any other aspects of its development (Crystal: 115).

There are many aspects to think about in naming a new product, such as marketing, linguistic, legal point of view. Linguistics which deals with a language has an important role in this case. There are some linguistic parameters that can be used in naming a product. Firstly is the possibility of offensiveness. A name is built up from letters and sound that may have impolite meaning to a certain language. It is important to create a product name which does not offend the others, mostly the name designed for international market. Secondly, name must be easy to pronounce and to spell by many people within different languages. The buyer will not buy something that they even cannot say its name, so it is necessary to create a simple name in the case of sound and letters. 
The Analysis of English Word Formations Used on Brand Names Found in Indonesian Products

Thirdly, memorable name is important. By creating a simple name it is hopefully that the product be easily recognized and remembered by the people.

An interesting and unique name will be preferable and recognizable for a consumer, so being creative is indeed needed in naming a new product. To create an interesting and unique product name sometimes can be gained by using linguistics aspect however it is not that easy because it needs creativity. The creator of the name must be able to cultivate a word, sound of a certain language to create a product name. $\mathrm{He}$ sometimes uses not only words or sound of their own language but also those of other languages.

English is still a foreign language but it has a prestigious position in Indonesia, because English is an international language. Nowadays, there are many Indonesian companies used English word to name their product. It does not mean that they are not proud of their own language. Even though they use English words, they do some adjustment within Indonesian. They use English words for go- international purpose.

We can find many products sold used English words in Indonesia. They use English because they are produced in Indonesia but under license of foreign companies such as Coca Cola, Marlboro, and Shell. They are all brands produced from English speaking country companies, however there are also English names used by a non English speaking country company such as Morinaga, Japan which produces milk for children name Chilmil, Chilkid, Chilscol in Indonesia.

The other products used English word is originally Indonesian products but named in English. We are familiar enough with soffel, so klin, bismart, etc. They are all Indonesian product but their names are 
derived from English words. Soffel is from the words soft [sof] and felt [fæl], so klin is from the word so [so] and clean [klin], bismart is biscuits and smart. The first and the last example experience the process of blending and the second example experiences the process of adjustment with the Indonesian language in the case of pronunciation.

There are many product names in Indonesia used English created by such kind of way. The writer is interested at these phenomena. The writer wants to analyze the used of English in product names found in Indonesia. Since there is an opinion that English is a prestigious language so there are many Indonesian products used English. Perhaps by using English, the product will be recognized not only locally but also globally. The researchers want to describe how the English brand names found in Indonesia are formed.

\section{Brand Name}

Branding is one of the strategies in marketing. A brand can show an image related to a product or a company visually, emotionally, rationally and even culturally. The brand may become a final consideration of a consumer before buying the products or using the service offered. The brand is the identity of a specific product, service, or business. The brand consists of all information dealing with the products or services. It is used to distinguish one product from another. In other words, it is a mark used to show ownership. When several companies sell a similar product, it is important that the brand name be clearly seen on the packaging and easily recognizable.

There are global and local brands. A global brand is a brand which is sold the same product to international market but it has its origin and 
The Analysis of English Word Formations Used on Brand Names Found in Indonesian Products

creates strong relationship with the consumers across countries and cultures. The examples of global brand are Coca Cola, Marlboro, and Shell. Even though they still have their origin, global brand may be different among the countries. This difference depends on the language, culture, style of communication, consumption pattern, market condition, legal and regulatory environment, and national approaching to marketing. While a local brand is a brand sold in a relatively small and restricted geographical area. It is usually ca be found only in one region.

A brand can take many forms, including a name, sign, symbol, color combination or slogan. A brand is the personality identifying a product, service or company (name, term, sign, symbol, or design, or combination of them). Brand name is a part of product consisting of letters, words and numbers. A legally protected brand name is called a trademark. Brand logo, on the other hand, is an element of a product consisting symbols and pictures.

Brand names come in many styles. Brand names sometimes come in acronym such as UPS or IBM. Names that describe the benefit and function of a product sometimes can show a brand name, such as fatigon which is derived from fatigue and gone. This product functions to reduce the fatigue. This one is called descriptive. Alliteration and rhyme can be used to show a brand name, such as Dunkin' Donuts, Tini Wini Biti. The other style is evocative, name that evoke a relevant vivid image like Amazon. A brand name may also come in a completely new word such as Kodak. We call it coining. Foreign word adaptation can be used to create a brand name such as Volvo or Samsung. A brand name is sometimes named after the founders' names for instance Disney, 
Hewlett-Packard. Many brands are named for regions and landmark like Fuji Film.

\section{English Word Formation.}

A word is the smallest of the linguistic units which can occur on its own speech and writing. In writing, word boundaries are usually recognized by spaces between the words and in speech, word boundaries may be recognized by slight pauses (Richard: 311). Words are important in a language. Language as a means of communication needs a media to communicate it and it can be achieved by a word.

Words in a language develop in numbers and variations as time goes by. As one of the languages in the world, English words experiences the same thing as those of the others languages. There are many sources of new English words such as borrowing from other languages, compounding, affixation, coining, etc. The process of new word creation is called a word formation. Besides, the growth of science also contributes a big part in the introduction of new words. There are many kinds of word formation in English, such as affixation, compounding, reduplication, coinage, blending, acronym, clipping, onomatopoeia.

1. Affixation

Affixation is a word formation by adding certain affixes whether they are prefixes or suffixes to the root. For instance happiness (happy+ -ness), careless (care+ -less), unpredictable (un+ predict+-able), etc.

2. Compounding

When we combine two or more words to produce a single word with new meaning, it means we apply compounding. 
Compounding process results on compound words such as sunlight (sun+light), ladybird (lady+bird), lighthouse (light+house), etc.

3. Reduplication

To reduplicate means to repeat the whole or partial words for instance very-very, hanky-panky. The reduplication serves different function among languages. In Indonesia, the reduplication can mean plural, such as rumah-rumah or house in English.

4. Coinage

It is the creation or invention of totally new terms, without employing any other words already in existence. They mostly originated from invented trade marks for example are Kodak, Kleenex, Nokia, etc.

5. Acronym

It comes from the initial sound (letter or letters) of the words or of a phrase and it is pronounced as a word. We can find acronyms in NATO, OPEC, ILO, KEPO etc.

6. Blending

It means to combine the parts of two words to produce a new word. The first part of the first word is blended with the last part of the second word. The examples are breakfast and lunch become brunch, education and entertainment become edutainment, etc.

7. Clipping

It is to cut or to shorten the longer word, such as in advertisement becomes ads, information becomes info, and laboratory becomes 
lab. New words sometimes are produced by imitating the sound of animals or other things such gun, boom explosion.

8. Onomatopoeia.

New words sometimes are produced by imitating the sound of animals or other things such gun, boom explosion. It means we use onomatopoeia to form a word.

\section{Research Methodology}

This is a descriptive qualitative research. The data of the research were brand names with English in Indonesian products found in the supermarket in Solo. The chosen supermarkets are Hypermart Solo Grand Mall, Hypermart Gorro Assalam, and Carefur. The three supermarkets are considered to be representative ones in Solo. The data were taken from February up to April 2010. The researchers used observation and documentation to collect the needed data. After collecting the data, the researchers classified the data based on the kind of products. Then the data were analyzed based on how they are formed using word formation process. The last step is drawing the conclusion.

\section{Compounding}

The writer found 116 brand names formed by compounding. Compounding words found in this research were classified into two kinds; they are pure compounding and modified compounding. Modified compounding happens when there is adaptation process with Indonesian language. The followings are several data representing for those two kinds of compounding. 
The Analysis of English Word Formations Used on Brand Names Found in Indonesian Products

\section{a. Pure Compounding}

Pure compounding means combining two words to form a new word with a new meaning. The followings are the examples of brand names applying pure compounding;

\begin{tabular}{|c|l|l|}
\hline No & \multicolumn{1}{|c|}{ Brand names } & \multicolumn{1}{c|}{ Word formation } \\
\hline 1 & Baby happy & Baby (N)+happy (Adj) \\
\hline 2 & Skin white & Skin (N)+white (Adj) \\
\hline 3 & Sunlight & Sun (N)+light (N) \\
\hline 4 & Bee jelly & Bee (N)+jelly (N) \\
\hline 5 & My lady & My (Adj)+lady (N) \\
\hline 6 & Care free & Care (V)+free (Adj) \\
\hline 7 & Weight gain & Weight (N)+gain (V) \\
\hline 8 & Tropicana slim & Tropicana (N)+slim (Adj) \\
\hline 9 & Milky day & Milky (Adj)+day (N) \\
\hline 10 & Greenfield & Green (Adj)+field (N) \\
\hline 11 & Slimming tea & Slimming (Ving)+tea (N) \\
\hline 12 & Fruit punch & Fruit (N)+punch (N) \\
\hline 13 & Country choice & Country (N)+choice (N) \\
\hline 14 & Fruit tea & Fruit (N)+tea (N) \\
\hline 15 & Fitactive & Fit (V)+active (Adj) \\
\hline 16 & Fit up & Fit (V)+up (prep) \\
\hline 17 & Cheese cracker & Cheese (N)+cracker (N) \\
\hline 18 & Juicy fruit & Juicy (Adj)+fruit (N) \\
\hline 19 & Rose brand & Rose (N)+brand (N) \\
\hline 20 & Swallow globe & Swallow (N)+globe (N) \\
\hline
\end{tabular}

All brand names above are formed by combining of two words and to create the new words with the new meanings. The words combined may be the same part of speech such as brand names number $3,4,12,13,14,19,20$ or the different ones such as those in 1, 2, 5, 6, 7, $8,9,10,11,15,16,17,18$.

\section{b. Modified Compounding}

Modified compounding happens when the words combined undergo some adjustment. The writer finds pronunciation and writing 
adjustment into Indonesian language. The following table lists brand names applying modified compounding;

\begin{tabular}{|c|c|c|c|c|}
\hline No & Brand Name & Original Words & Writing & Pronunciation \\
\hline 1 & Stefit & Stay+fit & Stay fit & {$[$ steI $]+[$ fit $]$} \\
\hline 2 & Hilo [hailo] & High+low & High low & {$[$ hai $]+[$ loU $]$} \\
\hline 3 & Soffel & Soft+felt & Soft felt & {$[$ sof $]+[$ fel $]$} \\
\hline 4 & Frais well & Fries + well & Fries well & [frais] $+[$ wel] \\
\hline 5 & Fatigon & Fatigue+gone & Fatigue gone & {$[$ fatig $]+[$ gon $]$} \\
\hline 6 & Kukizereal : & Cookie + cereal & Cookie cereal & [kUki] + [sIriəl] \\
\hline 7 & Lofet & Low + fat & Low fat & {$[$ loU $]+[$ fæet $]$} \\
\hline 9 & Chooey choco & Chewy+ choco & Chewy choco & {$\left[\mathbf{t} \int \mathbf{u i}\right]+[\mathrm{t}$ [oko $]$} \\
\hline 10 & Chilmil & Child+milk & Chil milk & {$\left[\mathbf{t} \int\right.$ ail $]+[\mathrm{mil}]$} \\
\hline 11 & Soklin & So + clean & So clean & {$[$ so $]+[$ klIn $]$} \\
\hline 12 & Jas jus & Just + juice & Just juice & {$[$ jas $]+[$ jus $]$} \\
\hline 13 & Nu face & $\mathrm{New}+$ face & New face & {$[\mathbf{n U}]+[$ feis $]$} \\
\hline 14 & Frestea & Fresh+tea & Fresh tea & {$[$ fræ []$+[\mathrm{ti}]$} \\
\hline
\end{tabular}

The examples above show the modified compounding because there are some adjustment applied to the words combined. The brand names are written based on their English pronunciation. The brand names, however, are not written in English writing system. For example brand name stefit which comes from stay [steI] dan fit [fit] is not written stay fit. This naming process is for the easiness of pronouncing the brand names. For the Indonesian where English is still considered as a foreigner language, it is easier to read stefit than stay fit. The rest of the brand names listed on the table above apply the same way of naming process of stefit.

\section{Blending}

The writer found 41 brand names applying blending in this research. They were classified into 8 groups. This classification is based on the syllable blended in creating the brand names. 
a. The first syllable of the first word and the first syllable of the second word.

\begin{tabular}{|c|l|l|l|}
\hline No & \multicolumn{1}{|c|}{ First words } & Second words & \multicolumn{1}{|c|}{ Brand Names } \\
\hline 1 & Yogurt & Ice & Yogice \\
\hline 2 & Popular & Ice & Popice \\
\hline 3 & Nestle & Tea & Nestea \\
\hline 4 & mountain & Tea & Mountea \\
\hline 5 & Yogurt & Fit & Yofit \\
\hline 6 & Rich & Cheese & Richeese \\
\hline 7 & Rich & Chip & Richip \\
\hline 8 & biscuit & Smart & Bismart \\
\hline 9 & maximum & Tea & Maxtea \\
\hline 10 & biscuit & chocolate & Bischoc \\
\hline 11 & wet & Tissue & Wetties \\
\hline
\end{tabular}

The examples above are formed by blending the first syllable of the first words and the first syllable of the second ones. The second words of the data above mostly consist of one syllable only so that the blending involves the first syllable of the first word and all the second words, such as in data number $1,2,3,4,5,6,7,8$. On the other hand, for data number $9,10,11$, the blending involves the first syllable of the first words and the first syllable of the second words

b. The first syllable of the first words and the second syllable from the front of the second words

\begin{tabular}{|c|l|l|l|}
\hline No & \multicolumn{1}{|c|}{ First words } & \multicolumn{1}{|c|}{ Second words } & \multicolumn{1}{|c|}{ Brand Names } \\
\hline 1 & Floor [flor] & Protection & Florex \\
\hline 2 & Sun [san] & Protection & Sanex \\
\hline 3 & Window & Protection & Windex \\
\hline 4 & Porcelain [pors] & Protection & Porstex \\
\hline 5 & Soft & Protection & Softex \\
\hline
\end{tabular}

The brand names above are formed by blending of the first syllable of the first words and the second syllable from the front of the second 
words. Having blended, the brand names are written in the same way of their English pronunciation; however they are not written using English spelling. Sanex is derived from sun [san] and protection [protæk[ion]. This brand name is written sanex instead of sunect. The sound /æk/ from protection [protæk/iən] seems difficult to be recognized by Indonesian; therefore the sound /akk/ is changed into /ex/ that have similar sound and is easier to pronounce as well. The similar process also is also occurred in the rest of the data above.

\section{c. The first words and the last syllable of the second words}

\begin{tabular}{|c|l|l|l|}
\hline No & \multicolumn{1}{|c|}{ First words } & \multicolumn{1}{|c|}{ Second words } & \multicolumn{1}{c|}{ Brand Names } \\
\hline $\mathbf{1}$ & happy & potatos & happytos \\
\hline $\mathbf{2}$ & wet & napkin & wetkin \\
\hline $\mathbf{3}$ & cheese & potatos & cheetos \\
\hline
\end{tabular}

The brand names listed on the table are formed by blending the first words and the last syllable of the second words. Three brand names are blended right away without any adjustment on pronunciation and spelling.

\section{d. The first words and two syllables from the front of the second} words.

\begin{tabular}{|c|l|l|l|}
\hline No & \multicolumn{1}{|c|}{ First words } & \multicolumn{1}{c|}{ Second words } & \multicolumn{1}{c|}{ Brand names } \\
\hline 1 & rich & chocolate & richoco \\
\hline 2 & for & vitamin & forvita \\
\hline
\end{tabular}

The two brand names above are formed by blending the first words and the two syllables from the front of the second words. The blending involves no spelling and pronunciation adjustment. 
e. Two syllables from the front of the first words and the second words

\begin{tabular}{|c|c|c|c|}
\hline No & First words & Second words & Brand names \\
\hline 1 & Indonesia & Milk & Indomilk \\
\hline 2 & Vitamin & Zone & Vitazone \\
\hline 3 & Vitamin & Charm & Vitacharm \\
\hline 4 & Vitamin & Milk & Vitamilk \\
\hline 5 & Chocolate [t $\left.\int \mathrm{ok}(\partial) 1 \mathrm{It}\right]$ & Chip & Chocochip \\
\hline 6 & Chocolate [t $\left.\int \mathrm{ok}(\partial) 1 \mathrm{It}\right]$ & Balls & Chocoballs \\
\hline 7 & 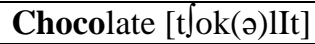 & mania & Chocomania \\
\hline
\end{tabular}

The data are formed by blending two syllables from the front of the first words and the second words. Data number 1, 2, 3, 4 has no adjustment from the spelling and pronunciation point of view. They are just blended right away. Data number 5, 6, 7 experience no spelling adjustment, however they undergo pronunciation adjustment. The brand names, mainly the two syllables from the front of the first words are pronounced in Indonesian pronunciation even though the spelling of the brand names is in English, such as the table below;

\begin{tabular}{|c|l|l|l|}
\hline \multirow{2}{*}{ No } & \multirow{2}{*}{ Writing of brand names } & \multicolumn{2}{|c|}{ Pronunciation of brand names } \\
\cline { 3 - 4 } & & \multicolumn{1}{|c|}{ English } & Indonesian \\
\hline 1 & chocochip & {$[\mathrm{t}$ okə $\mathrm{Ip}]$} & {$[$ cokocIp] } \\
\hline 2 & chocoballs & {$[\mathrm{t}$ ok $(\partial)$ bals] } & {$[$ cokobols] } \\
\hline 3 & chocomania & {$[\mathrm{t}$ okəmeInio] } & [cokomania] \\
\hline
\end{tabular}

f. Two syllables from the front of the first words and the first syllable of the second words

\begin{tabular}{|c|l|l|l|}
\hline No & \multicolumn{1}{|c|}{ First words } & \multicolumn{1}{c|}{ Second words } & \multicolumn{1}{c|}{ Brand names } \\
\hline 1 & calcium & maximum & calcimex \\
\hline 2 & nutrition & mama & nutrima \\
\hline 3 & nutritious & jelly & nutrijell \\
\hline 4 & protect & calcium & protecal \\
\hline
\end{tabular}


All the brand names above are formed by blending two syllables from the front of the first word and the first syllable of the second word. On the brand name Calcimex, there is an adjustment on its writing. The brand name is spoken in English pronunciation but not in English spelling. Calcimex is from Calcium and Maximum [mæksəməm]. Mex which is from the pronunciation of max /mæk/ is chosen instead of max on the process of blending. For the brand name Protecal, the first word is protect which only consists of two syllables so that word is just blended with no cutting.

\section{g. The first word and two last syllables from the back of the second} word.

\begin{tabular}{|c|l|l|l|}
\hline No & First words & Second words & Brand names \\
\hline 1 & fruit & vitamin & fruitamin \\
\hline 2 & chip & potato & chitato \\
\hline
\end{tabular}

Those brand names are formed by blending the first word and the two last syllables from the back of the second word. Both brand names are right away blended with no adjustment on either writing or spelling.

h. The first word and the first syllable of the second word.

\begin{tabular}{|c|l|l|l|}
\hline No & \multicolumn{1}{|c|}{ First words } & \multicolumn{1}{|c|}{ Second words } & \multicolumn{1}{c|}{ Brand names } \\
\hline 1 & Stick & chocolate & stico [stiko] \\
\hline 2 & Stick & chocolate & Stikko \\
\hline 3 & Twist & chocolate & Twistko \\
\hline 4 & Brick & chocolate & Briko \\
\hline 5 & Sweet & tissue & Sweeties \\
\hline 6 & Diabetes & solution & Diabetasol \\
\hline 7 & Diabetes & milk & Diabetamil \\
\hline
\end{tabular}

The brand names above are formed by blending the first word and the first syllable of the second word. Brand names number 5 and 6 are 
blended right away with no adjustment either writing or spelling. Brand name number 1 uses adjustment on writing. The first syllable of the second word (chocolate) namely cho is simplified into co so that it becomes stico read [stiko]. Brand names number 2, 3, and 4 apply an adjustment on writing after the process of blending. The way of writing the brand name is adapted with Indonesian spelling. The syllable cho is written into ko because the sound of /ch/ is closely to the sound of /c/ which is read with the sound of $/ \mathrm{k} /$ in Indonesian. The results of the blending process of the brand names should be stikcho, twistcho, brikcho, but they are adapted into stikko, twisko, briko. Brand name number 7 undergoes omission of letter on the second word after the words are blended. The second word, milk, is written into mil.

\section{Affixation}

The researchers found 21 English brand names formed by affixation. The following are the data found:

\section{a. Suffix $-\mathbf{y}$}

\begin{tabular}{|c|l|l|}
\hline No & Roots and suffixes & Brand names \\
\hline 1 & Sweet + y & Sweety \\
\hline 2 & Cream + y & Creamy \\
\hline 3 & Fit + y & Fitty --- fitti \\
\hline 4 & Down + y & Downy \\
\hline
\end{tabular}

Those brand names are formed by adding suffix $-\mathrm{y}$ on the words followed. There is no changing on the process of affixation applying on the brand names except for brand name number 3 as shown below:

$$
\text { Fit }+ \text { y fitty Fitti }
$$


b. Suffix -er

\begin{tabular}{|c|l|l|}
\hline No & \multicolumn{1}{|c|}{ Roots and Suffixes } & \multicolumn{1}{c|}{ Brand names } \\
\hline 1 & Blast + er & Blaster \\
\hline 2 & Twist + er & Twister \\
\hline 3 & Creame + er [krimər] & Kreamer \\
\hline
\end{tabular}

The brand names above are formed by adding suffix -er on the word followed. No adaptation on writing or pronunciation found on the affixation process applied on brand name number 1 and 2. However, there is an adaptation on writing and pronunciation found on the affixation process applied on brand name number 3. The sound /c/ in English is read into the sound $/ \mathrm{k} /$ in Indonesian. The affixation of brand name number 3 should result in Creamer but then it is written into Kreamer. This adaptation is due to the easy pronunciation for Indonesian people.

\section{c. Suffix -ness}

\begin{tabular}{|c|l|l|}
\hline No & \multicolumn{1}{|c|}{ Roots and suffixes } & \multicolumn{1}{c|}{ Brand names } \\
\hline 1 & Well + ness & Wellness \\
\hline 2 & Soft+ness & Softness \\
\hline
\end{tabular}

Brand names above are formed by adding suffix -ness on the word followed. There is no adaptation on writing and pronunciation.

\section{d. Suffix -ish}

\begin{tabular}{|c|l|l|}
\hline No & \multicolumn{1}{|c|}{ Roots and suffixes } & Brand names \\
\hline 1 & Brown + ish & Brownish ---- broniz \\
\hline
\end{tabular}

Brand name above is formed by adding suffix -ish on the word followed. There is an adaptation process found on the process of affixation. Brand 
The Analysis of English Word Formations Used on Brand Names Found in Indonesian Products

name above is written in English pronunciation for brownish [broniz] and to simplify it is just written Broniz

\section{Suffix - s}

\begin{tabular}{|c|l|l|}
\hline No & Roots and suffixes & Brand names \\
\hline 1 & Pamper + s & Pampers \\
\hline 2 & Chocolate --- chocolato + s & Chocolatos \\
\hline 3 & Wing + s & Wings \\
\hline 4 & Huggy + s ---- huggies & Huggies \\
\hline 5 & Sport + s ---- sportz & Sportz \\
\hline 6 & Wet + s ---- wetz & Wetz \\
\hline 7 & Mint + s ---- mintz & Mintz \\
\hline
\end{tabular}

The brand names are formed by adding suffix $-\mathrm{s}$ to the words followed. There is no adaptation found on the process of affixation on brand names number 1, 3, and 4 . The process of adaptation is found on the brand name number 2. Chocolatos is from chocolate. The changing of chocolate into chaocolatos is associated to the Italian word that often uses sound /o/. Italian is familiar with chocolate product and Italian chocolate is so famous all around the world so when talking about chocolate product, it will be associated with Italy and its language. The process of the affixation as follow;

Chocolate ------chocolato+s ----chocolatos

There's a changing of affixation process applied on the brand name number 5,6 , and 7 . The suffix $-\mathrm{s}$ is changed into $-\mathrm{z}$ due to the pronunciation variation. Suffix $-\mathrm{s} /-\mathrm{es}$ as has three allomorphs, namely /s, z, iz/.

\section{e. Prefix pro-}

\begin{tabular}{|c|l|l|}
\hline No & \multicolumn{1}{|c|}{ Prefixes and Roots } & \multicolumn{1}{c|}{ Brand names } \\
\hline 1 & Pro+clean [klIn] & Proclin [proklIn] \\
\hline 2 & Pro+dental & Prodental \\
\hline
\end{tabular}


All the brand names above use prefix pro-. Brand name number 1 uses combination both Indonesian and English pronunciation. The diphthong ea in the word clean which is pronounced /I/ is written with i, meanwhile the brand name is still used the letter $\mathrm{c}$ for the word clIn but it is pronounced with Indonesian pronunciation [klIn]. The second brand name has no special adjustment in the affixation process.

\section{f. Prefix bio-}

\begin{tabular}{|c|l|l|}
\hline No & \multicolumn{1}{|c|}{ Prefixes and roots } & \multicolumn{1}{c|}{ Brand names } \\
\hline 1 & Bio + clean & Bioklin \\
\hline 2 & Bio + kid & Biokid \\
\hline
\end{tabular}

Brand names above use prefix -bio on the word followed. Brand name number 1 uses combination both Indonesian and English pronunciation. The diphthong ea in the word clean which is pronounced/I/ is written with $\mathrm{i}$, meanwhile the brand name is still used the letter $\mathrm{c}$ for the word clIn but it is pronounced with Indonesian pronunciation [klIn]. The second brand name has no special adaptation in the affixation process.

\section{Reduplication}

There are 8 brand names found applying reduplication. The following brand names are:

\begin{tabular}{|c|l|}
\hline No & \multicolumn{1}{|c|}{ Brand names } \\
\hline 1 & Pet-pet \\
\hline 2 & Beng-beng \\
\hline 3 & Ring-ring \\
\hline 4 & Tini wini biti \\
\hline 5 & Choky-choky \\
\hline 6 & Coca-cola \\
\hline 7 & Chic-choc \\
\hline 8 & Snips-snaps \\
\hline
\end{tabular}


Brand name number 1, 2, 3 apply pure reduplication. It means the reduplication process which repeats all the words. The word pet is actually from the word pat [pæt] and to pronounce it easily the word is written into pet. The same process happens to beng which is derived from the word bang [bæy]. The next reduplication is on brand name number 5 which applies pure reduplication too. Choky is derived from the word chocolate but it is clipped so it becomes choco $\left[\mathbf{t} \int \mathbf{o k}\right]$ and then suffix $-\mathrm{y}$ is added so it becomes chocky which means a lot of chocolate.

Reduplication applied on brand name number 4 is used to give intensifier. Tini Wini Biti is derived from tiny winy bity mean very small. It is a product of biscuit with small size.

Brand names number 6,7 , and 8 undergo the same process of reduplication. The process of reduplication occurs by sound changing such as vowel changing in brand name chic-choc, snips-snaps and consonant changing in brand name coca-cola. The table below shows the sound changing:

\begin{tabular}{|c|l|l|l|}
\hline No & \multicolumn{1}{|c|}{ Roots } & \multicolumn{1}{|c|}{ Sound changing } & Reduplication \\
\hline 1 & Chic $[\mathrm{t}[\mathbf{I} \mathrm{k}]$ & Choc $\left[\mathrm{t} \int\right.$ o k] & Chic-choc \\
\hline 2 & Snips [snIps] & Snaps [snæps] & Snips-snaps \\
\hline 3 & Coca [koukə] & Cola [koulə] & Coca-cola \\
\hline
\end{tabular}

\section{Onomatopoeia}

The researchers found 5 brand names using onomatopoeia such as;

\begin{tabular}{|c|l|}
\hline No & Brand names \\
\hline 1 & Pet-pet \\
\hline 2 & Beng-beng \\
\hline 3 & Ring-ring \\
\hline 4 & Boom \\
\hline 5 & Snips-snaps \\
\hline
\end{tabular}


Pet-pet is derived from the word pat. Pat means to strike something lightly with palm of the hand or something flat. The sound of patting is imitated and used to give a name of a brand name. Beng-beng is derived from the word bang mean sound of gun. Ring-ring is from the word ring which means sound of bells. Brand name of candy name Boom is imitated the sound of explosion. Snip means the act or sound of using scissors to snip something and snap means a sharp sound: a short sound for example of something brittle suddenly or something clicking shut, in addition snap means to break with sharp noise: to break suddenly with a sharp cracking sound (Encarta Dictionaries). So we can conclude that both snip and snap are words dealing with producing sound.

\section{Acronym and Abbreviation}

The researchers found 5 brand names formed by acronym and abbreviation. The brand names are classified into acronym since the abbreviation of the brand names can be pronounced as words. The followings are the brand names applying acronym;

\begin{tabular}{|c|l|l|}
\hline No & \multicolumn{1}{|c|}{ Brand names } & \multicolumn{1}{|c|}{ Pronunciation } \\
\hline 1 & FC (Feminine Comfort) & [ef-si] \\
\hline 2 & SOS & [es-ou-es] \\
\hline 3 & Zevit C (Zinc Vitamin C) & [ze-vit-si] \\
\hline 4 & Vitalong C (Vitamin Long C) & [vita-long-si] \\
\hline 5 & Mi-U (me you) & [mi-yu] \\
\hline
\end{tabular}

Besides, the researchers also found 3 brand names applying abbreviation.

The followings are the brand names applying abbreviation;

\begin{tabular}{|c|l|l|}
\hline No & \multicolumn{1}{|c|}{ Brand names } & \multicolumn{1}{c|}{ The Longer foms } \\
\hline 1 & Redoxon CDR & Redoxon Calcium D Redoxon \\
\hline 2 & Oxygen dw & Oxygen drink water \\
\hline 3 & WPC & Wings Porcelain Cleaner \\
\hline
\end{tabular}


The Analysis of English Word Formations Used on Brand Names Found in Indonesian Products

\section{Clipping}

The researchers found 8 brand names formed by clipping. The brand names consist of longer words but due to the simplicity, they are clipped or cut into shorter ones. These are the brand names applying clipping process;

\begin{tabular}{|c|l|l|}
\hline No & \multicolumn{1}{|c|}{ Original words } & \multicolumn{1}{c|}{ Brand names } \\
\hline 1 & Fresh & Fres \\
\hline 2 & Luxurious & Lux \\
\hline 3 & Chocolate & Choc \\
\hline 4 & Frozen & Froz \\
\hline 5 & Kiss & Kis \\
\hline 6 & Give & Giv \\
\hline 7 & Lavender & Lavenda \\
\hline 8 & Fantasy & Fanta \\
\hline
\end{tabular}

The brand names using clipping can be categorized into two groups based on the way how the words are clipped.

\section{a. Clipping the letters}

\begin{tabular}{|c|l|l|}
\hline No & \multicolumn{1}{|c|}{ Original Words } & \multicolumn{1}{c|}{ Brand names } \\
\hline 1 & Fresh & Fres \\
\hline 2 & Kiss & Kis \\
\hline 3 & Give & Giv \\
\hline
\end{tabular}

The three brand names above are simplified by clipping the last letter of the brand names. It is for the easiness of pronunciation and the simplicity of the writing or spelling.

b. Clipping the syllables

\begin{tabular}{|c|l|l|}
\hline No & \multicolumn{1}{|c|}{ Original words } & \multicolumn{1}{c|}{ Brand names } \\
\hline 1 & Luxurious & Lux \\
\hline 2 & Chocolate & Choc \\
\hline 3 & Frozen & Froz \\
\hline 4 & Lavender & Lavenda \\
\hline 5 & Fantasy & Fanta \\
\hline
\end{tabular}


The five brand names mentioned are clipped by cutting the last syllables. The brand name number 4 is added with new letter [a] after it is cut. Sound changing /ə/ into /a/ like in lavender [lævəndə] becomes lavenda [lavenda] is sometimes found in English used by Afro-American such as the words girl $[\mathrm{ga}(\mathrm{r}) 1]$ that is often written or read gal and kind of [kaindev] that is often written or read kinda [kinda]. That is common in English especially in informal English to simplify the form.

\section{Conclusion}

English can be used to create brand names found in Indonesian product by applying the word formation. The use of English in Indonesian product undergoes writing (spelling) and reading (pronunciation) adjustment to Indonesian language. This adjustment is due to the cultural factor and easiness especially in pronunciation. The research found that brand names using English in Indonesian products can be created through compounding, blending, affixation, reduplication, onomatopoeia, abbreviation, acronym and clipping.

The research concluded that the process of compounding covers pure compounding and modification compounding. The modification is found in the form of writing (spelling) and reading (pronunciation). The process of blending includes the first syllable of the first words and the first syllable of the second words, the first syllable of the first words and the second syllable from the front of the second words., the first words and the last syllables of the second words, the first words and two syllables from the front of the second words, two syllables from the front of the first words and the second words, two syllables from the front of the first words and the first syllable of the second words, the first words 
and the two last syllables from the back of the second words, and the first words and the first syllables of the second words.

The affixation consists of applying prefixes such as pro-, -bio and applying suffixes such as $-\mathrm{y}$, -er, -ness, -ish, and $-\mathrm{s}$. The process of reduplication covers pure reduplication, reduplication with intensifier meaning, and reduplication with sound change. The onomatopoeia consists of imitation of sound produced by nature and things such as a gun. The process of abbreviation consists of pure abbreviation and acronym. The process of clipping includes omission of letter and syllables

\section{References}

Asib, A. 2004, English Morphology (handout), English Department Faculty of Teacher Training and Education, UNS.

Cheverton, P. 2002, If You're So Brilliant How Come Your Brand Isn't Working Hard Enough (terjemahan). Jakarta: PT Elex Media Komputindo.

Crystal, D. 2003, The Cambridge Encyclopedia of Language, Press Syndicate of the University of Cambridge, New York.

Durianto, D., Lie, J.B., and Sugiarto. 2004. Brand Equity Ten Strategi Memimpin Pasar. Jakarta: PT Gramedia Pustaka Umum.

Kridalaksana, H. 2001. Kamus Linguistik. Jakarta: PT Gramedia Pustaka Umum..

Matthews, P. 1997. The Concise Oxford Dictionar of Linguistics. New York: Oxford University Perss Inc.

Moleong, J.L. 2008. Metodologi Penelitian Kualitatif Edisi Revisi. Bandung: PT.Remaja Rosdakarya.

Moser, M. 2008.United We Brand (terjemahan). Jakarta: Esensi.

Richards, J., John P., and Heidi, W. 1985, Longman Dictionary of Applied Linguistics. England: Longman Group Limited. 
Giyatmi, Endang Dwi Hastuti, Ratih Wijayava, Sihindun Arumi

Subana, S. 2001.Dasar-dasar Penelitian Ilmiah.CV Pustaka Setia, Bandung.

Sukardi. 2006. Penelitian Kualitatif-Naturalistik Dalam Pendidikan, Usaha Keluarga, Yogyakarta 
The Analysis of English Word Formations Used on Brand Names Found in Indonesian Products 